УДК 355.233 (477:004)

Михайло Орда, кандидат технічних наук, старший науковий співробітник Національний університет оборони України імені Івана Черняховського, м. Київ ORCID ID 0000-0003-0374-3881

Сергій Федчук, Національний університет оборони України імені Івана Черняховського, м. Київ ORCID ID 0000-0002-3358-6648

Максим Мигун

Національний університет оборони України імені Івана Черняховського, м. Київ ORCID ID 0000-0001-5476-1276

DOI: $10.33099 / 2617-1775 / 2021-02 / 167-181$

\title{
ТЕХНОЛОГІЧНІ АСПЕКТИ ПОБУДОВИ СИСТЕМИ ЗБОРУ ТА ОБРОБКИ ІНФОРМАЦІЇ ЩОДО ОЦІНЮВАННЯ ЯКОСТІ ОСВІТИ ВИПУСКНИКІВ ВВНЗ
}

Досліджено питання щцодо технологічних аспектів побудови системи збору та обробки інформачії щцодо оцінювання якості освіти випускників ВВНЗ за підсумками службової діяльності.

Ключові слова: інформачиійна технологія; система збору та обробки інформації; програмне забезпечення; вищий військовий навчальний заклад; якість освіти; професійний стандарт; компетентність; оцінювання; службова діяльність; випускник.

Постановка проблеми. Система вищої військової освіти є складною соціальною, динамічною, ієрархічною освітньо-науковою структурою, що створюється та функціонує з метою забезпечення якості підготовки військових фахівців, наукових і науково-педагогічних працівників, підвищення їхньої кваліфікації відповідно до потреб ЗС України та інших військових формувань, утворених відповідно до законодавства.

Функціонування військової освіти як цілісної системи здійснюється на основі концептуальних засад розвитку та чинних нормативно-правових актів у сфері вищої військової освіти.

Основним показником якості підготовки військового фахівця - здобувача вищої освіти (випускника) ВВНЗ та ВНП ЗВО - $є$ сформованість у нього відповідних компетентностей, які визначені відповідним стандартом вищої освіти за спеціальністю та професійним стандартом військового фахівця Збройних Сил України (професійним стандартом офіцера тактичного рівня), що характеризуються ступенем здатності i готовності до постійного самовдосконалення, застосування особистих якостей і ціннісних орієнтирів при виконанні службових (бойових) функцій у військах (силах) в умовах мирного 
та воєнного часу на посаді за призначенням.

Кожна компетентність за спеціальністю, яка визначена стандартом вищої освіти та професійним стандартом офіцера тактичного рівня містить певні професійно важливі якості, прояв яких визначається сформованістю відповідних знань, умінь та навичок, які необхідні для виконання випускниками в майбутньому службових (бойових) функцій у військах (силах) на відповідній посаді за призначенням.

Вивчення професійної (службової) діяльності офіцера-випускника (виконання ним службових (бойових) функцій) на протязі першого року служби у військах (силах) та його оцінювання за підсумками службової діяльності здійснюється командирами (начальниками) всіх рівнів у процесі повсякденної служби, за результатами яких складається відгук, який направляється до ВВНЗ та ВНП ЗВО, який він закінчив.

Збір і обробки інформації щодо оцінювання якості освіти випускників ВВНЗ та ВНП ЗВО за підсумками їх службової діяльності у військах та розробка ВВНЗ та ВНП ЗВО рекомендацій щодо удосконалення навчальних планів. програм навчальних дисциплін. які забезпечують формування необхідних компетентностей, методів та методик з підготовки військових фахівців $є$ важливою складовою в організації та забезпеченні освітнього процесу.

Традиційні підходи до управління освітнім процесом, системою підготовки військових фахівців у ВВНЗ та ВНП ЗВО, де перевага надається функції періодичного контролю, аналізу отриманої інформації щодо оцінювання якості освіти випускників у паперовому вигляді, виявляються не здатними до оперативного, комплексного та прогнозованого реагування на зміни, що відбуваються як у внутрішньому освітньому процесі, так і навколо, не сприяють сталому та прогнозованому розвитку системи підготовки військових фахівців.

Тому, дослідження 3 метою розроблення системи збору і обробки інформації щодо оцінювання якості освіти випускників ВВНЗ та ВНП ЗВО за підсумками їх службової діяльності та оперативного внесення відповідних змін в систему та зміст підготовки військових фахівці у ВВНЗ та ВНП ЗВО $\epsilon$ актуальним і дозволить здійснювати гнучке управління процесом підготовки військових фахівців на основі системи супровідного оцінювання, аналізу, коригування та прогнозування.

Аналіз останніх досліджень i публікацій. Засади побудови інформаційних систем збору та обробки даних були закладені фундаментальними та системо утворюючими працями низки видатних українських вчених: В.М. Глушков, І.М. Коваленко, М.З. Згуровський, I.B. Сергієнко, П.І. Андон. Значний внесок в питання подальшого розвитку інформаційних технологій був внесений закордонними дослідниками.

Наукові результати були отримані в ході проведення досліджень у рамках виконання науково-дослідних робіт: шифр “Сирена” (№ 0120U000211) та шифр “Сирена-М” (№ 0121U000121).

Мета статті - дослідження проблематики щодо технологічних аспектів 
побудови системи збору та обробки інформації щодо оцінювання якості освіти випускників ВВНЗ за підсумками службової діяльності.

Методи дослідження - методи військово-технічного аналізу, системного аналізу, методи порівняння та аналогії, узагальнення й систематизації теоретичних знань; а також методи узагальнення та абстрагування.

\section{Виклад основного матеріалу.}

У сучасних інформаційних системах технічні засоби збору та обробки інформації використовуються комплексно на основі техніко-економічного розрахунку, доцільності їх застосування 3 урахуванням співвідношення "ціна/якість" та надійності роботи технічних засобів.

Процес збору інформації щодо оцінювання якості освіти випускників ВВНЗ та ВНП ЗВО за підсумками їх службової діяльності (відгуків) від командирів військових частин можливо за допомогою фельд’ єгерськопоштового зв'язку (ФПЗ), системи “СЕДО” або за допомогою автоматизованої інформаційної системи.

Використання ФПЗ може здійснюватися в окремих випадках посадовими особами підрозділів, які наприклад, залучаються до виконання завдань у районі проведення операцій Об'єднаних сил, а також здійснюють взаємодію Збройних Сил України з органами державної влади та іншими силовими структурами 3 питань обміну всіма видами кореспонденції у встановлені строки та під жорстким і суворим контролем.

На виконання збору інформації щодо оцінювання якості освіти випускників ВВНЗ та ВНП ЗВО за підсумками їх службової діяльності не впливають раптові фактори відмов, зокрема притаманні автоматизованим системам управління та загалом телекомунікаційним мережам, такі як відсутність електроживлення телекомунікаційної апаратури, електромагнитні завади, негативні наслідки впливу диверсійних груп супротивника.

Процес збору інформації щодо оцінювання якості освіти випускників ВВН3 та ВНП ЗВО за підсумками їх службової діяльності (відгуків) від командирів військових частин можливий за допомогою системи "СЄДО".

Робота системи "СЄДО" здійснюється шляхом доставки електронних повідомлень використовуючи сучасну телекомунікаційну мережу у найкоротший термін із можливістю захисту інформації та збереженням даних.

Тому в якості використання системи збору і обробки інформації щодо оцінювання якості освіти випускників ВВНЗ та ВНП ЗВО потрібно використовувати автоматизовану інформаційну систему (AIC), яка об'єднує в собі всі інженерно-технічні засоби збору та обробки інформації в один єдиний комплекс в тому числі методику збору та обробки інформації, яка включає порядок розробки, класифікацію і загальні вимоги до інформації, а також перелік засобів, необхідних для виконання робіт з реалізації збору та обробки даних.

Одним з головних переваг AIC $є$ широкі можливості для аналізу зібраної інформації.

Передбачається, що зібрана інформація буде використовуватися різними структурними підрозділами ВВН3 та ВНП ЗВО: навчальним відділом, 
факультетом, кафедрою, групою психолого-педагогічного забезпечення для визначення якості освіти.

Більш грунтовно розглянемо відокремлений функціональний вузол системи збору та обробки інформації. Розробка функціонального вузла системи 3ОI буде являти собою комплекс технічних, програмних, інформаційних, технологічних та організаційних засобів, призначених для інформаційноаналітичного забезпечення процесів підготовки, прийняття та контролю управлінських рішень шляхом своєчасного збору, накопичення, інтеграції, обробки та аналізу інформації про оцінювання якості освіти випускників ВВНЗ за підсумками їх службової діяльності. ФВ взаємодіє з інформаційною системою 3ОI шляхом об'єднання у корпоративну комп'ютерну мережу (ККМ).

Ефективне вирішення ряду задач, що постають перед фахівцями Міністерства оборони та Генерального штабу Збройних Сил України при виконанні ними своїх функцій та повноважень, сьогодні неможливе без використання сучасних комп'ютерних засобів, інформаційних технологій та відповідних баз даних, які кардинально впливають на такі характеристики процесів прийняття рішень певними підрозділами та особами, як ціна, якість, ефективність, оперативність. Ця обставина обумовлює невідкладне створення ФВ для інформаційно-аналітичного забезпечення процесів підготовки, прийняття та контролю управлінських рішень щодо оцінювання якості освіти випускників ВВНЗ.

Як перший крок до цієї мети $є$ створення технологічної бази інформаційної взаємодії ДВОН $з$ установами, що мають відношення оцінювання якості освіти випускників ВВНЗ.

Область використання ФВ буде охоплювати ресурси ЦП (в ДВОН та ГШ ЗСУ) та ВВНЗ.. В процесі створення ФВ повинні бути розроблені відповідні програмні засоби та реалізовані технічні рішення, які дозволять організувати інформаційну взаємодію ЦП та ВВНЗ при оцінювання якості освіти випускників 3 використанням Intranet технологій. Програмне забезпечення буде розгорнуто на автоматизованих робочих місцях ЦП та ВВНЗ, об’єднаних в ККМ.

Мета створення ФВ повинна досягатися вирішенням наступних задач:

1. Інтегруванням інформації, яка зберігається у тематичних базах даних, що розташовані в різних вузлах локальної мережі ЦП.

2. Поєднанням бази даних інформації щодо оцінювання якості освіти випускників з оперативною базою даних.

3. Розробки засобів представлення інформації користувачам незалежно від їх розташування з застосуванням Intranet технологій.

4. Наданням користувачам з боку ДВОН (Міністерства оборони України) можливості ведення особистої інформаційної вітрини даних.

5. Наданням користувачам з боку ДВОН (Міністерства оборони України) доступу до необхідних інформаційних ресурсів ГШ ЗСУ та зворотно, користувачам з боку ГШ ЗСУ доступу до окремих інформаційних ресурсів ДВОН (Міністерства оборони України).

6. Наданням користувачам ФВ можливості ведення автоматизованого внутрішнього документообігу. 
В процесі створення ФВ повинні бути розроблені відповідні програмні засоби та реалізовані технічні рішення, які дозволять організувати інформаційну взаємодію ДВОН (Міністерства оборони України), ГШ ЗСУ та ВВНЗ при оцінюванні якості освіти випускників ВВНЗ.

Результатами роботи буде:

доступ до інтегрованої інформації, яка зберігається у тематичних базах даних, що розташовані в різних вузлах локальної мережі;

поєднання бази даних пов'язаної інформації з оперативною базою даних;

розробка засобів представлення інформації користувачам незалежно від ïx розташування з застосуванням Intranet технологій;

надання користувачам з боку ДВОН (Міністерства оборони України) можливості ведення особистої інформаційної вітрини даних;

надання користувачам з боку ДВОН (Міністерства оборони України) доступу до необхідних інформаційних ресурсів ГШ ЗСУ і ВВНЗ та зворотно, користувачам з боку ГШ ЗСУ і ВВНЗ доступу до окремих інформаційних ресурсів ДВОН (Міністерства оборони України);

інструкції користувачам ФВ, опис програм, та навчання користувачів;

випробування та передача в дослідну експлуатацію компонентів першої черги ФВ;

стендові доповіді, демонстраційні версії розроблених програмних продуктів, презентаційний ролик.

У проекті термін інформатизація визначає процес впровадження в ДВОН передових інформаційних технологій на базі сучасних комп'ютерних i телекомунікаційних засобів, методів автоматизованої аналітичної обробки інформації, іiі оптимального збереження, пошуку та розповсюдження 3 метою інтеграції інформаційних ресурсів ГШ ЗСУ та ВВНЗ.

Об'єктом автоматизації є процеси інформаційно-аналітичної підтримки повсякденної діяльності фахівців ДВОН Міністерства оборони, ГШ ЗС України та ВВНЗ щодо вирішення проблем, пов'язаних з оцінювання якості освіти випускників ВВН3 за підсумками їх службової діяльності, на основі комплексної обробки інформації шляхом своєчасного збору, накопичення, інтеграції, обробки та аналізу відповідної інформації. ФВ для своєї роботи тісно взаємодіє з ГШ ЗСУ та ВВНЗ. ЦП в ГШ ЗСУ шляхом побудови та впровадження своєї власної підсистеми структурно об'єднує у собі ФКЗ своїх відділів. Елементи цієї структури просторово віддалені один від одного в межах управління - це окремі робочі місця в ГШ ЗСУ та ВВНЗ в регіонах. ЦП характеризується множиною інформаційних потоків, які $\epsilon$ вхідними та вихідними з нього, а також множиною внутрішніх потоків, що циркулюють між елементами структури ЦП. Крім того, в БД ЦП цілодобово накопичується множина відомчої інформації, яка зосереджується в певних місцях його структури. Характерною ознакою відомчої інформації $\epsilon$ відсутність сьогодні для неї єдиної системи уніфікації та стандартизації. Переважна більшість цієї інформації зберігається у базі даних та на паперових носіях, що не дозволяє достатньо оперативно здійснювати пошук необхідних даних та їх автоматизовану обробку. На сьогодні, на жаль, остаточно не вирішена задача 
правового оформлення відносин в області автоматизованого обміну комп'ютерною інформацією та взаємодії на державному рівні, що значно ускладнює налагодження відносин ФВ 3 конкретними структурами (міністерствами, відомствами та установами).

ФВ повинен мати доступ та інформаційно об'єднувати інформаційні ресурси підрозділів ГШ ЗСУ та ВВНЗ. Вони мають ієрархічні структури, елементи яких віддалені один від одного на певні відстані.

Інформаційні процеси, що підлягають автоматизації, характеризуються високими вимогами до оперативності, достовірності та повноти оброблюваної інформації, а також включають “вертикальні” міжрівневі інформаційні зв'язки між підсистемою ГШ ЗСУ та підрозділами регіональних структур ВВНЗ та «горизонтальні» інформаційні зв'язки між підрозділами одного рівня.

Наведемо перелік функцій відділу ДВОН, що автоматизуються в рамках ФВ:

1. Забезпечення ДВОН (Міністерства оборони України) інформацією щодо оцінювання якості освіти випускників ВВНЗ за підсумками їх службової діяльності.

2. Здійснення інформаційної взаємодії з ГШ ЗСУ та ВВНЗ 3 питань оцінювання якості освіти згідно затвердженого регламенту.

3. Отримання аналітичних довідок щодо оцінювання якості освіти.

4. Отримання статистичної інформації щодо оцінювання якості освіти.

5. Згідно затвердженого регламенту отримання ГШ ЗСУ інформації 3 ДВОН (Міністерства оборони України) по зверненнях, які стосуються оцінювання якості освіти.

6. Контроль виконання заходів щодо попередження оцінювання якості освіти.

7. Участь у формуванні і реалізації єдиної політики з питань військової освіти у сфері впровадження сучасних інформаційних технологій, банків даних для оцінювання якості освіти.

Відділ (ДВОН МОУ) у процесі виконання покладених на нього завдань взаємодіє з Генеральним штабом Збройних Сил України, командуваннями видів та ВВН3, а також іншими міністерствами та установами.

Основні проектні рішення щодо створення ФВ повинні бути реалізовані в завданнях та функціях відділу ДВОН МОУ, що автоматизуються, комп'ютерних базах даних, які потрібно інтегрувати, інформаційних технологіях, розгляді питань технічного і програмного забезпечення ФВ та захисту інформації. Нижче наведені найбільш важливі проектні рішення, які покладаються в основу створення ФВ.

В зв'язку 3 тим, що ФВ повинен бути складовою частиною загальноміністерської IAC, він має базуватися на системі технічних рішень щодо створення IAC. Основні проектні рішення сформульовані в концепції, технічному завданні на систему в цілому, технічних завданнях на окремі підсистеми, а також матеріалів інформаційного обстеження відповідних установ, їх задачах, що автоматизуються, комп'ютерних базах даних, інформаційних технологіях, а також при розгляді питань технічного i програмного забезпечення ФВ та захисту інформації. Нижче наведені найбільш 
важливі проектні рішення, які покладаються в основу створення підсистеми.

Запропоновані технічні рішення визначають базовий комплекс функцій вузла на прикладі взаємодії з ГШ ЗС України які у майбутньому плануються до впровадження у інших державних установах, що мають відношення до для оцінювання якості освіти.

Завдання, які покладені на відділ ДВОН згідно з положенням про нього, відображені вище. Їх детальний аналіз дозволив виявити та сформулювати сукупність завдань, які підлягають першочерговій автоматизації та інтеграції і повинні вирішуватися за допомогою сучасних комп'ютерних та програмних засобів і інформаційних технологій.

Головна проблема традиційної технології управління документообігом практична неможливість централізовано наглядати за рухом документів в організації в реальному масштабі часу, тому що це потребує великих працевитрат не тільки на ведення докладних журналів та картотек у кожному підрозділі (навіть якщо вони ведуться за допомогою комп'ютера), але і на оперативне централізоване зведення відповідної інформації.

Відсутність дієвої технології керування документообігом призводить до того, що у довільний момент часу неможливо визначити, над якими документами працює заклад, яка історія та поточний стан того чи іншого питання, чим конкретно зайняті виконавці.

В процесі створення ФВ для автоматизованого вирішення його задач важливе значення надається розробці вільного доступу до баз даних (БД), які вже використовуються і ті, що будуть розроблені для використання посадовими особами ДВОН та фахівцями його відділів при виконанні ними своїх службових обов'язків за призначенням. Повинен бути забезпечений доступ як до централізованих баз даних загального користування так і до спеціалізованих баз з використанням системи аутентифікації.

Доступ до централізованих інформаційних баз має буде забезпечений усім користувачам ККМ МО України, ГШ ЗСУ і ДВОН як iї абоненту.

Створення ФВ передбачає забезпечення санкціонованого доступу до трьох груп комп'ютерних баз даних для посадових осіб та фахівців ДВОН:

бази даних загального користування;

бази даних управлінь та відділів;

персональні бази даних.

Бази даних загального користування повинні містити у собі інформаційні фонди, доступні для використання у своїй роботі всім працівниками Міністерства, які об'єднані в ККМ.

Бази даних конкретних управлінь (відділів) повинні містити у собі інформаційні фонди, які доступні для використання у своїй роботі усім працівниками цього управління (відділу) та, при потребі, ФВ.

Персональні бази даних мають бути впроваджені на робочих станціях (АРМах) посадових осіб та фахівців конкретних структурних підрозділів міністерства. Ці бази даних повинні містити у собі персональні інформаційні фонди (ресурси), які будуть доступними конкретним особам для індивідуального користування при виконанні ними своїх функцій та 
повноважень, а також (у разі необхідності) можуть бути відображені на засобах колективного користування. При потребі ФВ також повинен мати доступ до цих даних.

Для підвищення ефективності повсякденної роботи фахівців та для забезпечення інформаційної сумісності з ЦП, підрозділами Міністерства, іншими державними установами потрібно установити на їх AРМах офісний пакет, який би забезпечив виконання повсякденних функцій - підготовку текстових документів, ведення персональних баз даних, нескладні розрахунки та моделі тощо. Де-факто в більшості державних установах найбільш популярний сьогодні пакет програм Microsoft Office, що включає в себе такі програмні продукти:

Microsoft Word - робота з текстами;

Microsoft Excel - pобота 3 електронними таблицями, нескладні розрахунки та моделювання;

Microsoft Power Point - підготовка презентаційних матеріалів;

Microsoft Access - персональна СУБД, що дозволяє будувати персональні бази даних та забезпечує доступ до них.

Технологія автоматизованого документообігу (ТАД) в ФВ буде охоплювати такі основні етапи автоматизованої обробки документів: прийом, реєстрацію, розгляд, передачу, відправку, інформаційно-довідкову роботу, оперативне зберігання, контроль виконання, систематизацію і класифікацію, формування справ, складання описів та передачу в архів. Ця технологія забезпечить створення єдиної інформаційної бази документів, що відображатиме всі етапи підготовки та проходження документів в ФВ. ТАД передбачає обробку як електронних так і звичайних документів на твердих копіях.

Технологія загального інформаційного обміну в ФВ та захисту інформації забезпечуватиме внутрішній інформаційний обмін між компонентами в контурі підсистеми та зовнішній інформаційний обмін з компонентами інших підсистем і комп'ютерних систем різних структур (міністерств, відомств тощо).

Електронна пошта об'єднує зовнішні об'єкти з ДВОН і є основним засобом транспортування електронних повідомлень та документів.

Всі повідомлення, що надходять або формуються у ДВОН розділяються на регламентні та поточні. Прийом всіх документів реєструється в відповідному журналі автоматизації документообігу підсистеми. Далі документи та повідомлення проходять технологічні маршрути, що визначені у ДВОН. Передбачається також ведення журналу регламентів отримання документів та повідомлень з зовнішніх об'єктів (структур) і контроль їх надходження. При відсутності документів, що повинні бути отримані по регламенту, формуються списки відсутніх документів та надсилаються запити до відповідних об'єктів (структур) на отримання необхідної інформації.

Технологія інформаційного обміну за допомогою змінних електронних та паперових носіїв інформації має такий же вигляд, як і засобами електронної пошти. В реєстрі документів та картотеці при цьому вказується тип носія інформації. Реєстрація документів для всіх видів інформаційного обміну 
здійснюється централізовано у журналах ТАД відповідним фахівцем. Інформаційний обмін повинен передбачати класифікацію інформаційних повідомлень, документів та створення системи формулярів i програмних засобів, що здійснюють автоматичний обмін інформацією між зовнішніми об'єктами та ДВОН.

Доступ до ресурсів мережі Internet буде забезпечено відповідним налагодженням системи віддаленого доступу та серверу Internet. При такому підході дешевше вартість цього інформаційного ресурсу. Для альтернативного шляху доступу до Internet у випадку пошкодження виділеного каналу зв'язку може бути використане підключення до одного з київських провайдерів Internet по комутірованим каналам.

Вирішальним фактором при створенні ФВ має бути вибір їі архітектури (Рисунок 1). Від обраного варіанта архітектури залежить якою буде ефективність підсистеми.

Під архітектурою ФВ слід розуміти загальну логічну організацію підсистеми, яка визначає процес іï функціонування та включає методи обробки даних, склад, фізичну структуру складових компонентів, призначення, принципи взаємодії технічних та програмних засобів, структуру мережі передачі даних та комп'ютерного зв'язку з урахуванням дисципліни з'єднань та їх топології, організацію баз даних (знань) і механізми доступу до них.

Вибір варіанта архітектури ФВ здійснюється 3 урахуванням ряду технічних вимог, які пред'являються до підсистеми. Основні з цих вимог такі:

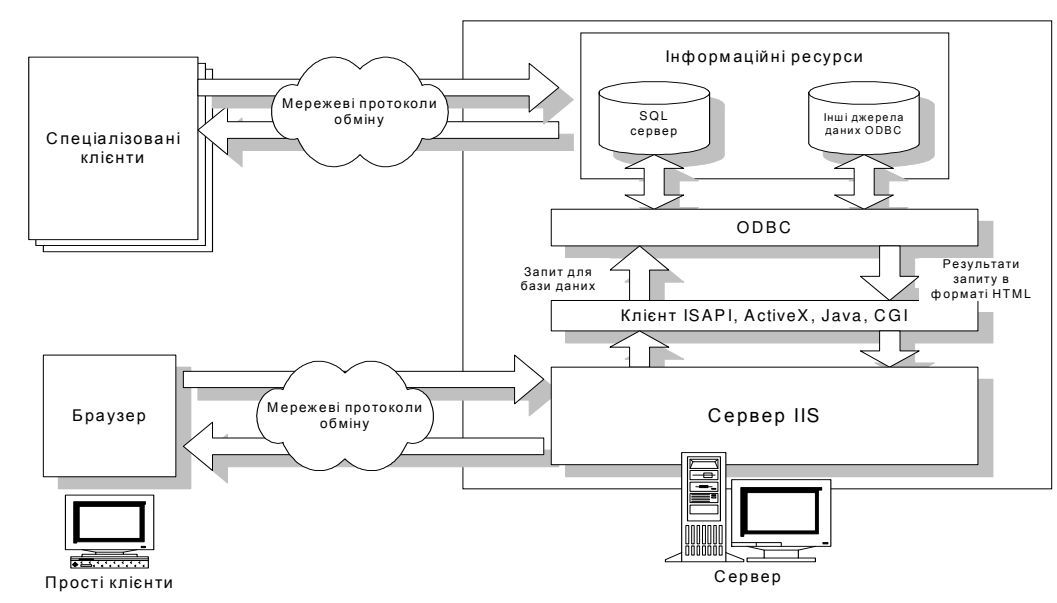

Рис 1. Схема архітектурного рішення стосовно ФВ

можливість до змін та налагодження на нові функціональні задачі; реакція підсистеми на запити користувачів в потрібний (певний) період часу;

можливість розширення застосувань;

технологічність експлуатації та супроводу підсистеми;

надійність функціонування;

ефективність використання обчислювальних та телекомунікаційних 
ресурсів;

базуватися на комунікаційних засобах відкритих систем, при якому ФВ повинен мати можливість взаємодії з іншими підсистемами та системами, використовуючи будь-який протокол та тип інформації;

забезпечення паралельного доступу до центральних, локальних та розподілених баз даних при умові дотримання цілісності даних та синхронізації доступу;

«легкий» доступ до даних при достатньо високих стандартах їх безпеки та цілісності (захист даних від несанкціонованого доступу і від змін під час передачі);

подолання відомчих бар'єрів щодо доступу до інформації;

впровадження та використання стандартизованих міжвідомчих рішень щодо інтерфейсів інформаційного взаємообміну та структур даних;

надійність швидких каналів передачі даних;

захист та конфіденційність інформації.

При виборі моделі доступу та підтримки баз даних ФВ необхідно враховувати широке застосування в сучасних відомчих (корпоративних) комп'ютерних системах передових технологій обробки інформації та ефективних механізмів доступу кінцевого користувача до даних. 3 такої позиції найбільш ефективною в архітектурі ФВ буде трьохрівнева модель: "клієнт сервер прикладних задач - сервер баз даних". Ця архітектура дозволить створити єдиний інформаційний простір, в якому кінцевий користувач підсистеми буде мати своєчасний i безперешкодний (але санкціонований!) доступ до відповідних інформаційних ресурсів.

Однією з найважливіших компонент архітектури ФВ внутрішня ЛКМ та засоби ії підключення до ККМ Міністерства оборони України, який забезпечує доступ користувачів підсистеми до різноманітних інформаційних фондів, що накопичені у відповідних інформаційних базах.

Технічне забезпечення ФВ включає технічне оснащення ДВОН, ЛКМ ВВНЗ та засоби їі підключення до ККМ міністерства.

Для ефективного функціонування ФВ у структурі міністерства необхідно iї включення до ЛКМ інших управлінь, введення у дію певних комп'ютерних та телекомунікаційних засобів, що об'єднаються конкретними локальними комп'ютерними мережами і становитимуть комплекс технічних засобів (КТЗ) міністерства.

Типовий комплекс технічних засобів, необхідних для ФВ, наведено на рисунку 2. 


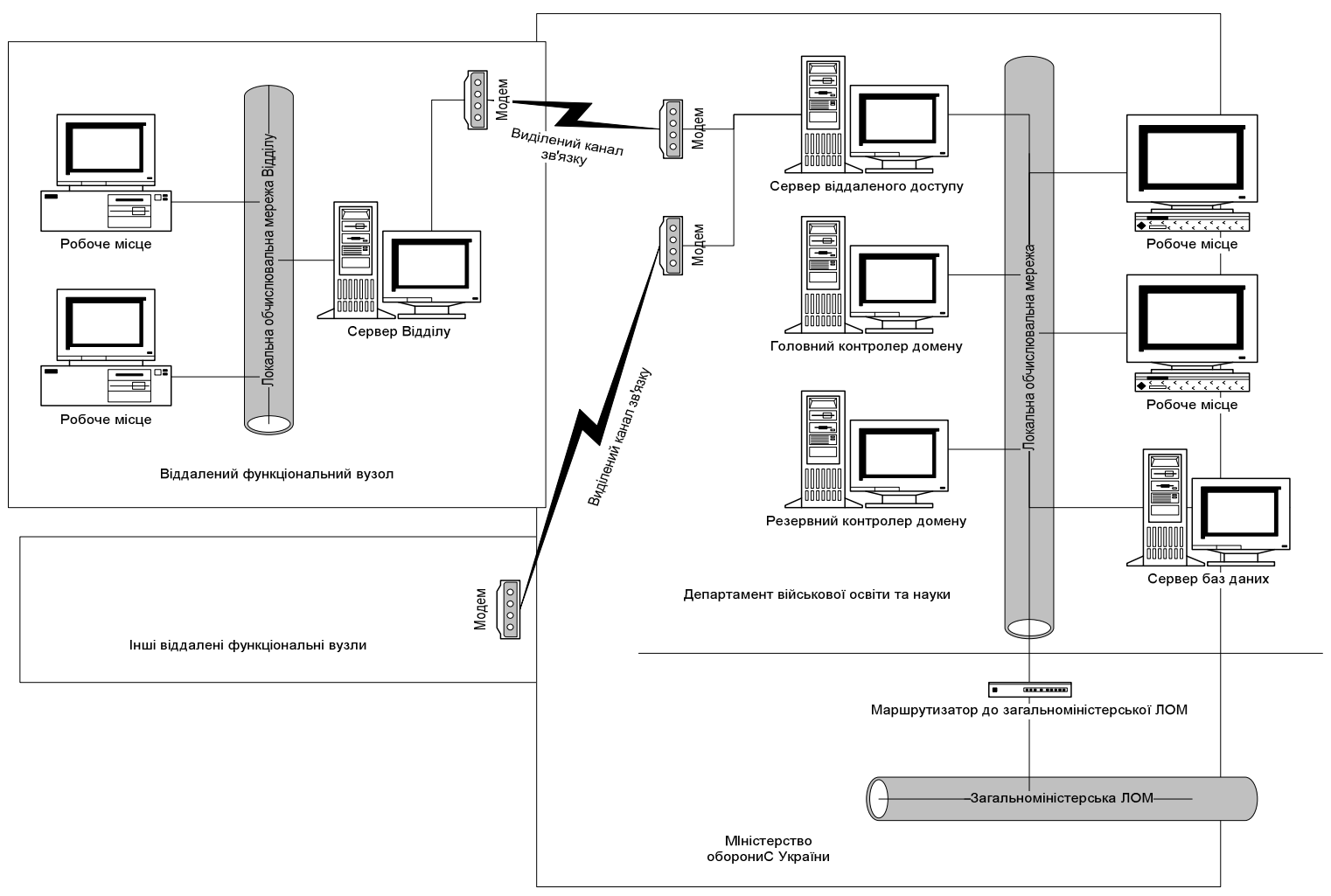

Рис. 2. Типовий комплекс технічних засобів ФВ

У випадку виходу з ладу виділеного каналу зв'язку чи серверу, може бути використаний такий мінімальний склад технічних засобів (рисунок 3 ).

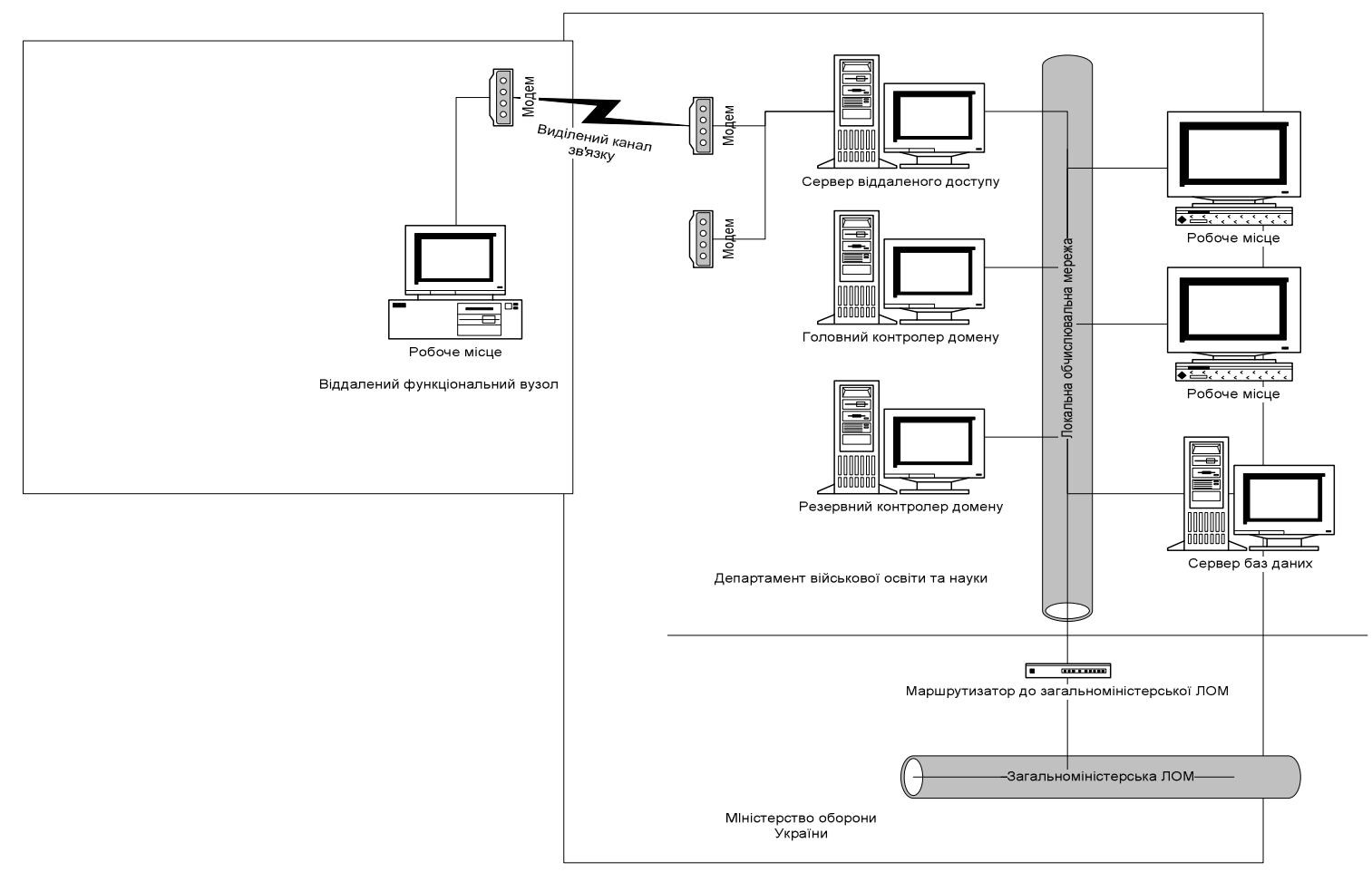

Рис. 3. Мінімальні технічні засоби ФВ. 
Висновки. Ефективне вирішення ряду задач, що постають перед фахівцями Міністерства оборони та Генерального штабу Збройних Сил України при виконанні ними своїх функцій та повноважень, сьогодні неможливе без використання сучасних комп'ютерних засобів, інформаційних технологій та відповідних баз даних, які кардинально впливають на такі характеристики процесів прийняття рішень певними підрозділами та особами, як ціна, якість, ефективність, оперативність. Ця обставина обумовлює невідкладне створення ФВ для інформаційно-аналітичного забезпечення процесів підготовки, прийняття та контролю управлінських рішень щодо оцінювання якості освіти випускників ВВНЗ.

Кінцевою метою створення підсистеми ФВ є забезпечення підвищення ефективності вироблення та впровадження управлінських рішень і контролю їх виконання при вирішенні проблем, пов'язаних оцінюванням якості освіти випускників ВВНЗ в Україні та за їі межами, на основі комплексної обробки інформації, а саме оперативних, аналітичних, нормативно-довідкових, експертних, статистичних та інших даних і матеріалів.

Напрями подальших досліджень Напрямом подальших досліджень $є$ створення інформаційної системи збору та обробки інформації щодо оцінювання якості освіти випускників ВВНЗ, гармонізованої із сучасними підходами у державах-членах НАТО, налагодження взаємного зв'язку замовник-виконавець на підставі створення єдиної бази даних та відповідного програмного забезпечення, у тому числі на платформі дистанційного навчання.

\section{ЛITEPATУРА}

1. Закон України "Про національну безпеку України" // [Електронний ресурс]. Режим доступу: http://zakon0.rada.gov.ua/laws/show/2469-19.

2. Закон України "Про освіту" // [Електронний ресурс]. - Режим доступу: http://zakon0.rada.gov.ua/laws/show/2145-19.

3. Закон України "Про вищу освіту" // "Голос України", 6 серпня 2014 року // [Електронний ресурс]. - Режим доступу: http://zakon0.rada.gov.ua/laws/show/1556-18.

4. Закон України "Про наукову та науково-технічну діяльність" // [Електронний pecypc]. - Режим доступу: http://zakon0.rada.gov.ua/laws/show/848-19.

5. Закон України "Про національну програму інформатизації". Відомості Верховної Ради України, 1998, №№ 27-28, ст. 181.

6. Закон України “Про Концепцію Національної програми інформатизації" від 04.02.1998 № 75/98-BP [Електронний ресурс]. - Режим доступу: http://zakon2.rada.gov.ua/laws/show/75/98-\%D0\%B2\%D1\%80.

7. Обгрунтування вимог до перспективної системи інформаційного забезпечення військової освіти і науки з урахуванням досвіду держав-членів НАТО, звіт про НДР шифр "Сирена" (заключний звіт) НУОУ ім. Івана Черняховського - м. Київ, 2020 р., 275 с.

8. Пьюривал С. Основы разработки веб-приложений / С. Пьюривал. - СПб.: Питер, 2015. -272 с.: ил.

9. Никсон Р. Создаем динамические веб-сайты с помощью PHP, MySQL, JavaScript, CSS и HTML5 / Р. Никсон. - 3-е изд. - СПб.: Питер, 2015. - 688 с.

10. Кармайкл Э. Быстрая и качественная разработка программного обеспечения / Э. Кармайкл, Д. Хейвуд. - Пер. с англ. - М.: Вильямс, 2003.

11. Колисниченко Д. Н. PHP и MySQL. Разработка веб-приложений / Д. Н. Колисниченко. - 5-е изд., перераб. и доп. - СПб.: БХВ-Петербург, 2015. - 592 с.: ил. 
12. Конноли Т. Базы данных: проектирование, реализация и сопровождение /. Т. Конноли , К. Бегг. - Теория и практика. - 3-е изд. - Пер. с англ. - М.: Вильямс, 2003

13.. Шаховська Н. Б. Проектування інформаційних систем: навчальний посібник / Н. Б. Шаховська, В. В. Литвин. - Львів: Магнолія 2006, 2011. - 384 с.

14. Jackson System Development / [Електронний ресурс]. - 2008. - Режим доступу : http://en.wikipedia.org/wiki/Jackson_System_Development

15. Bootstrap 3 /[Електронний ресурс] - Режим доступу: http://getbootstrap.com/.

\section{REFERENCES}

1. Law of Ukraine "On National Security of Ukraine" // [Electronic resource]. - Access mode: http://zakon0.rada.gov.ua/laws/show/2469-19.

2. Law of Ukraine "On Education" // [Electronic resource]. - Access mode: http://zakon0.rada.gov.ua/laws/show/2145-19.

3. Law of Ukraine "On Higher Education" // "Voice of Ukraine", August 6, 2014 // [Electronic resource]. - Access mode: http://zakon0.rada.gov.ua/laws/show/1556-18.

4. Law of Ukraine "On scientific and scientific-technical activities" // [Electronic resource]. - Access mode: http://zakon0.rada.gov.ua/laws/show/848-19.

5. Law of Ukraine "On the National Informatization Program". Information of the Verkhovna Rada of Ukraine, 1998, №№ 27-28, Art. 181.

6. Law of Ukraine "On the Concept of the National Informatization Program" of 04.02.1998 № 75/98-VR [Electronic resource]. - Access mode: http://zakon2.rada.gov.ua/laws/show/75/98$\%$ D0\%B2\%D1\%80.

7. Substantiation of requirements to the perspective system of information support of military education and science taking into account the experience of NATO member states, report on R\&D code "Sirena" (final report) Ivan Chernyakhovsky - Kyiv, 2020, 275 p.

8. Pyurival S. Fundamentals of web application development / S. Pyurival. - СПб .: Питер, 2015. - 272 с .: ил.

9. Nixon R. We create dynamic websites using PHP, MySQL, JavaScript, CSS and HTML5 / R. Nixon. - 3rd ed. - СПб .: Питер, 2015. - 688 c.

10. Carmichael E. Fast and high-quality software development / E. Carmichael, D. Haywood. - Per. with English - M .: Williams, 2003.

11. Kolisnichenko DN PHP and MySQL. Web application development / DN Kolisnichenko. - 5th ed., Reworked. and ext. - СПб .: БХВ-Петербург, 2015. - 592 с .: ил.

Connoli T. Databases: design, implementation and maintenance. T. Connolly, K. Begg. Theory and practice. - 3rd ed. - Per. with English - M .: Williams, 2003

13. Shakhovska NB Design of information systems: textbook / NB Shakhovska, VV Lytvyn. - Lviv: Magnolia 2006, 2011. - 384 p.

14. Jackson System Development / [Electronic resource]. - 2008. - Access mode: http://en.wikipedia.org/wiki/Jackson_System_Development

15. Bootstrap 3 / [Electronic resource] - Access mode: http:/getbootstrap.com/..

\section{РЕЗЮМЕ}

Михаил Орда, кандидат технических наук, старший научный сотрудник

Национальный университет обороны Украины имени Ивана Черняховского

Сергей Федчук,

Национальный университет обороны Украины имени Ивана Черняховского

Максим Мигун,

Национальный университет обороны Украины имени Ивана Черняховского 


\title{
Технологические аспекты построения системы сбора и обработки информации об оценивании качества образования выпускников ВВУЗ
}

Исследован вопрос про технологические аспекты построения системы сбора и обработки информации об оченивании качества образования выпускников ВВУЗ по итогам служебной деятельности.

Ключевые слова: информационная технология; система сбора и обработки информации; программное обеспечение; высшее военное учебное заведение; качество образования; профессиональный стандарт; компетентность; оиенивание; служебная деятельность; выпускник.

\section{SUMMARY}

\author{
Mikhailo Orda, \\ $\mathrm{PhD}$ (technical sciences), Senior Researcher \\ National Defence University of Ukraine \\ named after Ivan Chernyahovskyi \\ Sergey Fedchuk, \\ National Defence University of Ukraine \\ named after Ivan Chernyahovskyi \\ Maksym Mygun, \\ National Defence University of Ukraine \\ named after Ivan Chernyahovskyi
}

\section{Technological aspects of construction of the system of collection and processing of information regarding the assessment of the quality of education of higher education graduates}

The issue of question about the technological aspects of building a system for collecting and processing information on assessing the quality of education of university graduates based on the results of official activities.

Key words: information technology; information collection and processing system; software; higher military educational institution; quality of education; professional standard; competence; assessment; service activity; graduate.

Introduction. The system of higher military education is a complex social, dynamic, hierarchical educational and scientific structure that is created and operates to ensure the quality of training of military specialists, scientific and scientific-pedagogical workers, their training in accordance with the needs of the Armed Forces of Ukraine and other military formations. to legislation.

The main indicator of the quality of training of a military specialist - a graduate (graduate) - is the formation of relevant competencies, which are defined by the relevant standard of higher education in the specialty and professional standard of a military specialist of the Armed Forces of Ukraine (professional standard of tactical officer). readiness for constant selfimprovement, application of personal qualities and values in the performance of official (combat) functions in the troops (forces) in peacetime and wartime in the position assigned to them.

Purpose. Research on the technological aspects of building a system for collecting and processing information to assess the quality of education of university graduates on the basis of service activities.

Methods. methods of military-technical analysis, systems analysis, methods of comparison and analogy, generalization and systematization of theoretical knowledge; as well as methods of generalization and abstraction.

Result. Effective solution of a number of tasks facing the specialists of the Ministry of Defense and the General Staff of the Armed Forces of Ukraine in the performance of their functions 
and powers is impossible today without the use of modern computer tools, information technology and databases that dramatically affect such characteristics decisions by certain departments and individuals, such as price, quality, efficiency, efficiency. This circumstance leads to the immediate creation of $P V$ for information and analytical support of the processes of preparation, adoption and control of management decisions to assess the quality of education of university graduates.

Originality. The main problematic issues regarding the regulatory support for the assessment of educational results based on the results of the service activities of graduates of high military school of the Armed Forces are:

- the place of ensuring the quality of education as a systemic category requires the practical implementation of fundamentally new approaches in education management;

- there is no clear understanding of the stages of issues and regulations on the evaluation of educational results and training of graduates of high military school based on the results of official activity;

- there are no criteria for the relevant content and tools for the practical implementation in military education.

Addressing these issues is important and relevant given the improvement of the career development system of officers (service), achieving positive results in military education, forming a team of military professionals.

Conclusion. The direction of further research is to create an information system for collecting and processing information on assessing the quality of education of university graduates, harmonized with modern approaches in NATO member states, establishing customer-based communication through a single database and relevant software, including on the distance learning platform. 